\title{
Sphingobacterium siyangense sp. nov., isolated from farm soil
}

Correspondence
Ren Lai
rlai72@njau.edu.cn

\author{
Rui Liu, ${ }^{1} \dagger$ Huan Liu, ${ }^{2,3}$ † Chong-Xing Zhang, ${ }^{1}$ Shou-Yun Yang, ${ }^{1}$ \\ Xiu-Hong Liu, ${ }^{1} \mathrm{Ke}-Y$ un Zhang ${ }^{1}$ and Ren Lai ${ }^{1,2}$
}

${ }^{1}$ Key Laboratory of Microbiological Engineering of Agricultural Environment, Ministry of Agriculture, Life Sciences College of Nanjing Agricultural University, Nanjing, Jiangsu 210095, PR China

${ }^{2}$ Biotoxin Department of Key Laboratory of Animal Models and Human Disease Mechanisms, Kunming Institute of Zoology, Chinese Academy of Sciences, Kunming, Yunnan 650223, PR China

${ }^{3}$ Graduate School of the Chinese Academy of Sciences, Beijing 100009, China
The family Sphingobacteriaceae of the phylum Bacteroidetes (previously, the Cytophaga-Flavobacterium-Bacteroides group) currently comprises seven genera including Sphingobacterium and Pedobacter (Steyn et al., 1998) and [Flexibacter] canadensis (a misclassified Flexibacter species). The type genus Sphingobacterium was proposed originally by Yabuuchi et al. (1983) to include Gram-negative rods that are positive for catalase and oxidase, negative for heparinase, gelatinase and indole production and having iso- $\mathrm{C}_{15: 0}$, iso- $\mathrm{C}_{15: 0} 2-\mathrm{OH}, \mathrm{C}_{16: 1} \omega 7 c$ and $\mathrm{C}_{17: 0} 3-\mathrm{OH}$ as the main fatty acids. At the time of writing, the genus comprised eight recognized species, including Sphingobacterium multivorum, S. spiritivorum and $S$. mizutaii (Yabuuchi et al., 1983) [mizutae was corrected to mizutaii; Holmes et al. (1988)], S. antarcticum (Shivaji et al., 1992) [antarcticus was corrected to antarcticum; Euzéby (1998)], S. thalpophilum and S. faecium (Takeuchi \& Yokota, 1992), S. daejeonense (Kim et al., 2006) and S. composti (Yoo et al., 2007).

†These authors contributed equally to this work.

The GenBank/EMBL/DDBJ accession number for the 16S rRNA gene sequence of strain $S Y 1^{\top}$ is EU046272.

Transmission electron micrographs of cells of strain $S Y 1^{\top}$ are available as supplementary material with the online version of this paper.
A Gram-negative, aerobic, non-spore-forming bacterial strain (designated $\mathrm{SY}^{\mathrm{T}}$ ) was isolated from a farm-soil sample and subjected to a polyphasic taxonomy approach. Based on the resulting data, strain $S Y 1^{\mathrm{T}}$ is considered to represent a novel species of the genus Sphingobacterium.

Strain $\mathrm{SY}^{\mathrm{T}}$ was isolated using the dilution-plating technique on Luria-Bertani (LB) agar $\left(1^{-1}: 5 \mathrm{~g}\right.$ yeast extract, $10 \mathrm{~g}$ tryptone, $10 \mathrm{~g} \mathrm{NaCl} ; \mathrm{pH} 7.0$ ) incubated at $30{ }^{\circ} \mathrm{C}$ and was cultivated routinely on LB agar or in LB broth at the same temperature under aerobic conditions. Stock cultures were maintained as a glycerol suspension $(20 \%, w / v)$ at $-70{ }^{\circ} \mathrm{C}$.

Amplification of the 16S rRNA gene sequence was performed as described by Cui et al. (2001). The sequence obtained was compared with available sequences retrieved from GenBank using the BLAST program (http:// www.ncbi.nlm.nih.gov/blast/) to determine an approximate phylogenetic affiliation. Phylogenetic analysis was performed using the software packages PHYLIP (Felsenstein, 1993) and MEGA version 3.1 (Kumar et al., 2001) after multiple alignment of data using CLUSTAL_X (Thompson et al., 1997). Evolutionary distances (distance options according to the Kimura two-parameter model; Kimura, 1980,1983 ) and clustering were based on the neighbourjoining (Saitou \& Nei, 1987) and maximum-likelihood (Felsenstein, 1981) methods. Bootstrap analysis (1000 
replications) was used to evaluate the topology of the neighbour-joining tree (Felsenstein, 1985).

An almost complete 16S rRNA gene sequence (1489 bp) of strain SY1 ${ }^{\mathrm{T}}$ was obtained. The phylogenetic tree (Fig. 1) based on the neighbour-joining algorithm showed that strain $\mathrm{SY}^{\mathrm{T}}$ grouped among Sphingobacterium species and joined S. multivorum JCM $21156^{\mathrm{T}}$ (98.5\% similarity) with a high bootstrap value of $100 \%$. Strain $\mathrm{SY}^{\mathrm{T}}$ shared $<96.0 \% 16$ S rRNA gene sequence similarity with other recognized Sphingobacterium species.

DNA-DNA hybridization was carried out to evaluate the genomic DNA-DNA relatedness between strain $\mathrm{SY}^{\mathrm{T}}$ and S. multivorum JCM $21156^{\mathrm{T}}$ by using the optical renaturation rate method as described by De Ley et al. (1970), with the modifications described by Huß et al. (1983) and Escara \& Hutton (1980). Renaturation rates were computed with the program TRANSFER.BAS (Jahnke, 1992). Strain $S Y 1^{\mathrm{T}}$ exhibited low DNA-DNA relatedness with its closest relative S. multivorum JCM $21156^{\mathrm{T}}(2.2 \%)$. According to Stackebrandt \& Goebel (1994) and Wayne et al. (1987), the levels obtained for 16 rRNA gene similarity $(<97 \%)$ and DNA-DNA relatedness $(<70 \%)$ support the genomic distinction of strain $\mathrm{SY}^{\mathrm{T}}$ from other Sphingobacterium species.
Morphological features were examined by using transmission electron microscopy (Hitachi-7650) as described by Nedashkovskaya et al. (2005). Gram staining and endospore-forming features were investigated using light microscopy (model $\mathrm{BH} 2$; Olympus) according to the method described by Gerhardt et al. (1994). Anaerobic growth and growth at different temperatures and $\mathrm{pH}$ values were investigated according to Kim et al. (2006) and Xu et al. (2005), respectively, using LB as the basal medium. $\mathrm{NaCl}$ tolerance was tested using LB broth containing $0-5 \%$ (w/v) $\mathrm{NaCl}$. Growth was evaluated on cetrimide agar, Simmons' citrate agar, MacConkey agar and nutrient agar. All tests were incubated at $30{ }^{\circ} \mathrm{C}$ for 2 days. Oxidase activity was tested by determining the oxidation of $1 \%$ $(\mathrm{w} / \mathrm{v})$ tetramethyl- $p$-phenylenediamine (Merck) and catalase activity was evaluated by determining the production of oxygen bubbles in a $5 \%(\mathrm{v} / \mathrm{v})$ aqueous hydrogen peroxide solution. Hydrolysis of casein, gelatin, aesculin, starch, carboxymethylcellulose, Tween 80 and Tween 20 was tested on LB agar after 2 days incubation as described by Lányí (1987) and Gerhardt et al. (1994). Degradation of DNA (using DNase agar from Scharlau, supplemented with $1 \mathrm{M} \mathrm{HCl}$ ) and chitin was also investigated as described by Kim et al. (2006). Acid production from carbohydrates was determined using the medium and method described by

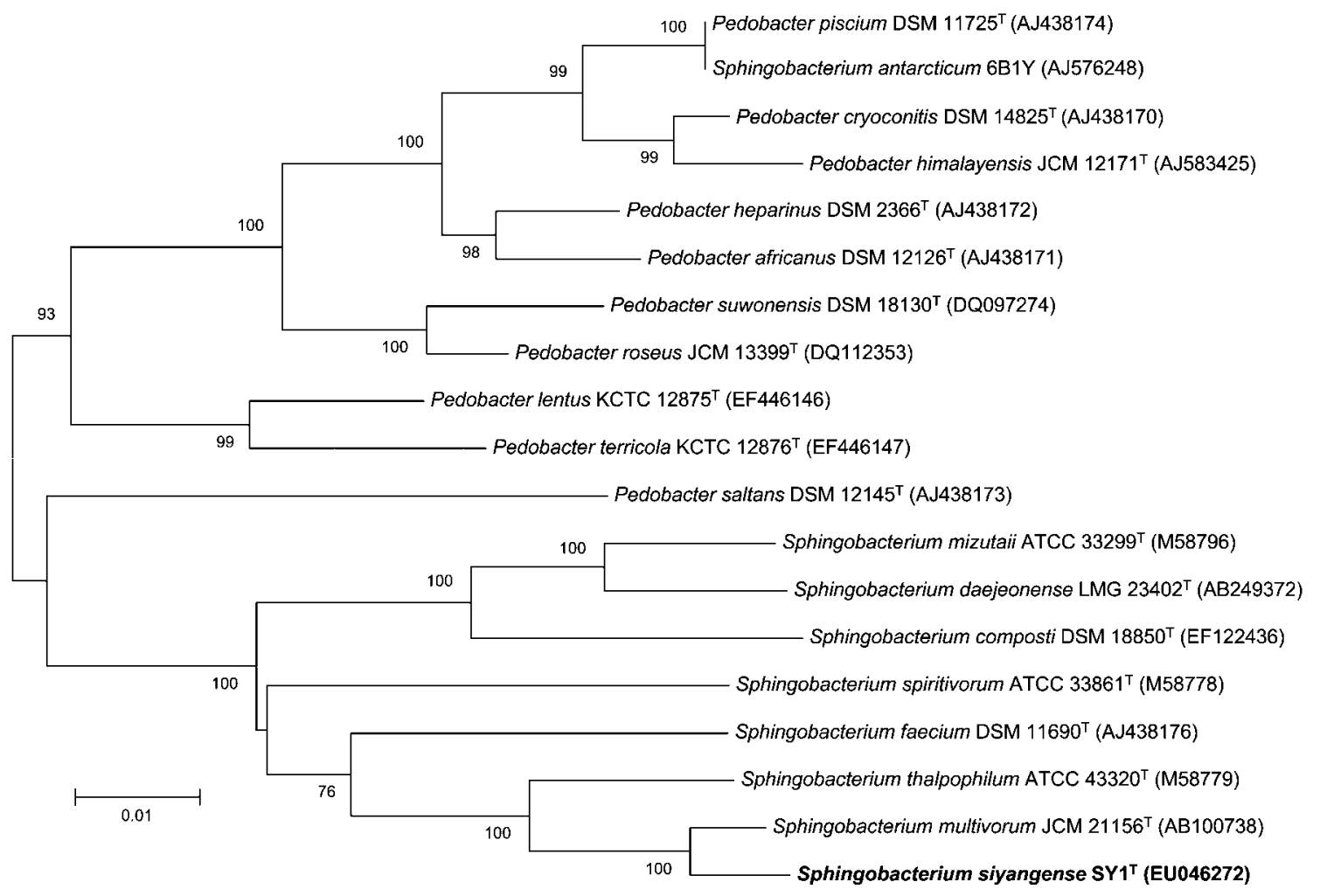

Fig. 1. Comparative analysis of the $16 \mathrm{~S}$ rRNA gene sequences of strain $S Y 1^{\top}$ and representative strains of the genus Sphingobacterium using the neighbour-joining method. Bootstrap values (expressed as percentages of 1000 replications) $>50 \%$ are shown at branching points. The maximum-likelihood tree showed essentially the same topology (data not shown). Bar, 0.01 substitutions per nucleotide position. 
Yamaguchi \& Yokoe (2000). Single carbon-source utilization was determined as described by Zhou et al. (2007). Some other biochemical characteristics, as given in the species description below, were tested using API 20E kits (bioMérieux) according to the instructions of the manufacturer. Antibiotic sensitivity tests were performed using the diffusion method as described by Park et al. (2007) on $\mathrm{LB}$ agar at $30{ }^{\circ} \mathrm{C}$ with filter-paper discs $(8 \mathrm{~mm}$ diameter; Sanofi Pasteur) containing the following antibiotics $(\mu \mathrm{g})$ : streptomycin (10), ampicillin (10), chloramphenicol (30), erythromycin (15), tetracycline (30), ofloxacin (5), rifampicin (5), gentamicin (10), ceftazidime (30), kanamycin (30), carbenicillin (100) and polymyxin B (30). After 2 days incubation, the diameters of the inhibition zones were measured. Phenotypic characteristics of strain $S Y 1^{\mathrm{T}}$ are given in the species description and in Table 1 . Transmission electron micrographs of cells of strain SY1 ${ }^{\mathrm{T}}$ are shown in Supplementary Fig. S1 (available in IJSEM Online).
Genomic DNA was extracted and purified according to Yoon et al. (1996) and the DNA G+C content was determined using the thermal denaturation method (Mandel \& Marmur, 1968). The $\mathrm{G}+\mathrm{C}$ content of the DNA of strain $\mathrm{SY}^{\mathrm{T}}$ was $38.5 \mathrm{~mol} \%$, within the range of values reported for members of the genus Sphingobacterium (37.3-44.2 mol\%; Yoo et al., 2007).

For quantitative analysis of the cellular fatty acid content, cells were harvested after 2 days growth at $30{ }^{\circ} \mathrm{C}$ on trypticase soy agar and fatty acid methyl esters were prepared and identified by following the instructions of the Microbial Identification system (MIDI), as described by Sasser (1990). The cellular fatty acids mainly comprised iso- $\mathrm{C}_{15: 0}(32.9 \%), \mathrm{C}_{16: 0}(10.9 \%)$ and summed feature 3 (iso- $\mathrm{C}_{15: 0} \quad 2-\mathrm{OH}$ and/or $\mathrm{C}_{16: 1} \omega 7 c \quad 24.1 \%$ ), typical of members of the genus Sphingobacterium (Takeuchi \& Yokota, 1992; Steyn et al., 1998). The cellular fatty acids of strain $\mathrm{SY}^{\mathrm{T}}$ are listed in Table 2 and compared with those

Table 1. Differential characteristics of strain $S Y 1^{\top}$ and related Sphingobacterium species

Strains: $1, \mathrm{SY}^{\mathrm{T}}$ (S. siyangense sp. nov.); 2, S. multivorum JCM $21156^{\mathrm{T}} ; 3$, S. thalpophilum ATCC $43320^{\mathrm{T}} ; 4$, S. faecium DSM $11690^{\mathrm{T}}$; 5, S. mizutaii ATCC $33299^{\mathrm{T}}$; 6, S. daejeonense LMG $23402^{\mathrm{T}}$; 7, S. spiritivorum ATCC $33861^{\mathrm{T}}$; 8, S. composti DSM $18850^{\mathrm{T}}$. Data were from Steyn et al. (1998), Kim et al. (2006), Yoo et al. (2007) and this study. +, Positive; -, negative; v, results vary between references; ND, no data available.

\begin{tabular}{|c|c|c|c|c|c|c|c|c|}
\hline Characteristic & 1 & 2 & 3 & 4 & 5 & 6 & 7 & 8 \\
\hline \multicolumn{9}{|l|}{ Growth at: } \\
\hline $4{ }^{\circ} \mathrm{C}$ & + & - & - & + & - & - & - & - \\
\hline \multicolumn{9}{|l|}{ Hydrolysis of: } \\
\hline DNA & + & + & - & + & + & - & + & - \\
\hline Starch & + & + & + & + & + & - & + & - \\
\hline Aesculin & - & + & + & + & + & - & + & + \\
\hline Tween 80 & - & $\mathrm{V}$ & - & $\mathrm{V}$ & + & ND & + & + \\
\hline Urea & + & + & + & + & + & - & + & - \\
\hline Tyrosine & - & $\mathrm{V}$ & - & - & + & - & - & - \\
\hline Lysine & + & - & - & - & V & - & - & ND \\
\hline \multicolumn{9}{|l|}{ Utilization of: } \\
\hline D-Ribose & + & - & - & - & - & - & - & - \\
\hline L-Sorbose & + & - & - & - & - & - & - & - \\
\hline L-Rhamnose & + & - & + & + & - & - & + & - \\
\hline L-Arabinose & + & + & + & + & $\mathrm{V}$ & - & - & + \\
\hline D-Mannitol & + & - & - & - & - & - & + & - \\
\hline Xylitol & + & - & - & - & - & - & - & - \\
\hline Adonitol & + & - & + & - & - & + & - & - \\
\hline Inulin & + & $\mathrm{V}$ & + & + & - & - & $\mathrm{V}$ & - \\
\hline Gluconate & + & - & - & - & - & - & - & - \\
\hline Glycerol & + & - & + & + & - & - & $\mathrm{V}$ & - \\
\hline \multicolumn{9}{|l|}{ Acid production from: } \\
\hline D-Glucose & - & + & + & + & + & + & + & - \\
\hline Sucrose & - & + & + & + & + & - & + & - \\
\hline Trehalose & + & - & - & - & - & - & - & + \\
\hline L-Rhamnose & + & $\mathrm{V}$ & + & - & - & - & - & - \\
\hline L-Arabinose & - & + & + & + & + & - & - & + \\
\hline Nitrate reduction & + & - & + & - & - & $\mathrm{ND}$ & - & - \\
\hline DNA G $+C$ content $(\mathrm{mol} \%)$ & 38.5 & $39.9-40.5$ & $44.0-44.2$ & 37.3 & $39.3-40.0$ & 38.7 & 39.8 & 42.3 \\
\hline
\end{tabular}


Table 2. Fatty acid contents (\%) of strain $\mathrm{SY} 1^{\top}$ and related Sphingobacterium species

Strains: $1, \mathrm{SY}^{\mathrm{T}}$ (S. siyangense sp. nov.); 2, S. multivorum JCM $21156^{\mathrm{T}}$; 3, S. thalpophilum ATCC $43320^{\mathrm{T}} ; 4$, S. faecium DSM $11690^{\mathrm{T}}$; 5, S. mizutaii ATCC $33299^{\mathrm{T}} ; 6$, S. daejeonense LMG $23402^{\mathrm{T}} ;$, S. spiritivorum ATCC $33861^{\mathrm{T}} ; 8$, S. composti DSM $18850^{\mathrm{T}}$. Data from Steyn et al. (1998), Kim et al. (2006), Yoo et al. (2007) and this study. Fatty acids amounting to less than $1.0 \%$ in all strains tested are not listed. tr, Trace $(<1.0 \%) ;-$, not detected; ECL, equivalent chain-length.

\begin{tabular}{|c|c|c|c|c|c|c|c|c|}
\hline Fatty acid & 1 & 2 & 3 & 4 & 5 & 6 & 7 & 8 \\
\hline anteiso- $\mathrm{C}_{15: 0}$ & 2.7 & - & - & $\operatorname{tr}$ & $\operatorname{tr}$ & 2.6 & $\operatorname{tr}$ & - \\
\hline iso- $\mathrm{C}_{15: 0} 3-\mathrm{OH}$ & 3.0 & 3.2 & 4.3 & 3.7 & 3.0 & 1.5 & 2.2 & 2.3 \\
\hline$C_{16: 0}$ & 10.9 & 7.8 & 6.0 & 4.5 & $\operatorname{tr}$ & 3.4 & 3.5 & 2.2 \\
\hline $\mathrm{C}_{16: 0} 2-\mathrm{OH}$ & $\operatorname{tr}$ & $\operatorname{tr}$ & 3.2 & - & - & - & - & - \\
\hline $\mathrm{C}_{16: 0}$ 10-methyl & - & - & - & 1.4 & - & - & - & - \\
\hline $\mathrm{C}_{16: 1} \omega 5 c$ & $\operatorname{tr}$ & - & - & 1.5 & $\operatorname{tr}$ & $\operatorname{tr}$ & $\operatorname{tr}$ & - \\
\hline iso- $\mathrm{C}_{17: 0} 3-\mathrm{OH}$ & 5.9 & 7.1 & 10.0 & 10.0 & 22.1 & 16.6 & 12.5 & 19.7 \\
\hline iso- $\mathrm{C}_{17: 1} \omega 9 c$ & 1.1 & $\operatorname{tr}$ & - & - & 3.7 & 2.9 & 1.7 & 2.9 \\
\hline Summed feature $3^{*}$ & 24.1 & 49.0 & 47.8 & 48.1 & 35.1 & 23.8 & 42.7 & 37.5 \\
\hline ECL 13.566 & $\operatorname{tr}$ & - & 1.4 & $\operatorname{tr}$ & 1.3 & 1.0 & $\operatorname{tr}$ & - \\
\hline
\end{tabular}

${ }^{*}$ Summed feature 3 contains iso- $\mathrm{C}_{15: 0} 2-\mathrm{OH}$ and/or $\mathrm{C}_{16: 1} \omega 7 c$.

of the type strains of phylogenetically related Sphingobacterium species.

On the basis of phylogenetic evidence and phenotypic distinctiveness (Table 1), it is proposed that strain SY $1^{\mathrm{T}}$ should be classified in the genus Sphingobacterium as representing a novel species, for which the name Sphingobacterium siyangense sp. nov. is proposed.

\section{Description of Sphingobacterium siyangense sp. nov.}

Sphingobacterium siyangense (si.yang.en'se. N.L. neut. adj. siyangense pertaining to Siyang in Jiangsu Province, China, the city where the strain was isolated).

Cells are Gram-negative, non-motile, non-spore-forming, strictly aerobic rods, $0.8-1.7 \mu \mathrm{m}$ long and $0.7-0.9 \mu \mathrm{m}$ wide. After 2 days incubation on LB agar, colonies are 1.0$2.0 \mathrm{~mm}$ in diameter, slightly yellowish, convex, circular and smooth with entire margins. Grows at $4-42{ }^{\circ} \mathrm{C}$ (optimum, 30-37 ${ }^{\circ} \mathrm{C}$ ), pH 3.0-10.0 (optimum, pH 6.08.0 ) and $0-4 \% \mathrm{NaCl}$ (optimum, $0-2 \%$ ). Growth occurs on nutrient agar and cetrimide agar, but not on Simmons' citrate agar or MacConkey agar. Positive for catalase and oxidase. In API 20E tests, positive for $\beta$-galactosidase, arginine dihydrolase, arginine decarboxylase, urease and nitrate reduction. Negative for ornithine decarboxylase, lysine decarboxylase, tryptophan deaminase, indole and $\mathrm{H}_{2} \mathrm{~S}$ production and Voges-Proskauer reaction. Starch, DNA, aesculin and Tween 20 are hydrolysed, but casein, gelatin, carboxymethylcellulose, Tween 80 or chitin are not. Acid is produced from trehalose and L-rhamnose, but not from D-glucose, cellobiose, D-galactose, sucrose, D-lactose, melezitose, melibiose, raffinose, D-mannitol, D-sorbitol or inositol. Utilizes D-xylose, melibiose, turanose, maltose, Dfructose, D-glucose, D-lactose, sucrose, L-sorbose, trehalose, D-galactose, raffinose, L-rhamnose, L-arabinose, cellobiose, D-ribose, D-mannose, melezitose, i-erythritol, adonitol, Larabitol, xylitol, D-sorbitol, D-mannitol, salicin, inulin, dextrin, $N$-acetyl-D-glucosamine, gluconate, lysine, amygdalin and glycerol, but not inositol, acetate, malonate or tyrosine. Resistant to streptomycin, kanamycin and polymyxin B, but sensitive to ceftazidime, chloramphenicol, erythromycin, tetracycline, ofloxacin, rifampicin, gentamicin, ampicillin and carbenicillin. The predominant fatty acids are iso- $\mathrm{C}_{15: 0}(32.9 \%), \mathrm{C}_{16: 0}(10.9 \%)$ and summed feature 3 (iso- $\mathrm{C}_{15: 0}$ 2-OH and/or $\mathrm{C}_{16: 1} \omega 7 c ; 24.1 \%$ ). The $\mathrm{G}+\mathrm{C}$ content of the DNA of the type strain is $38.5 \mathrm{~mol} \%$.

The type strain, SY $1^{\mathrm{T}} \quad\left(=\right.$ KCTC $\quad 22131^{\mathrm{T}}=\mathrm{CGMCC}$ $\left.1.6855^{\mathrm{T}}\right)$, was isolated from a soil sample from Jiangsu Province, PR China.

\section{Acknowledgements}

We are grateful for the financial support of the Chinese National Natural Science Foundation (30600001) and the Jiangsu Natural Sciences Foundation (BK2005422).

\section{References}

Cui, X. L., Mao, P. H., Tseng, M., Li, W. J., Zhang, L. P., Xu, L. H. \& Jiang, C. L. (2001). Streptomonospora salina gen. nov., a new member of the family Nocardiopsaceae. Int J Syst Evol Microbiol 51, 357-363.

De Ley, J., Cattoir, H. \& Reynaerts, A. (1970). The quantitative measurement of DNA hybridization from renaturation rates. Eur $J$ Biochem 12, 133-142. 
Escara, J. F. \& Hutton, J. R. (1980). Thermal stability and renaturation of DNA in dimethyl sulfoxide solutions: acceleration of renaturation rate. Biopolymers 19, 1315-1327.

Euzéby, J. P. (1998). Taxonomic note: necessary correction of specific and subspecific epithets according to Rules $12 \mathrm{c}$ and $13 \mathrm{~b}$ of the International Code of Nomenclature of Bacteria (1990 Revision). Int J Syst Bacteriol 48, 1073-1075.

Felsenstein, J. (1981). Evolutionary trees from DNA sequences: a maximum likelihood approach. J Mol Evol 17, 368-376.

Felsenstein, J. (1985). Confidence limits on phylogenies: an approach using the bootstrap. Evolution 39, 783-791.

Felsenstein, J. (1993). PHYLIP (phylogeny inference package), version 3.5c. Distributed by the author. Department of Genome Sciences, University of Washington, Seattle, USA.

Gerhardt, P., Murray, R. G. E., Wood, W. A. \& Krieg, N. R. (editors) (1994). Methods for General and Molecular Bacteriology. Washington, DC: American Society for Microbiology.

Holmes, B., Weaver, R. E., Steigerwalt, A. G. \& Brenner, D. J. (1988). A taxonomic study of Flavobacterium spiritivorum and Sphingobacterium mizutae: proposal of Flavobacterium yabuuchiae sp. nov. and Flavobacterium mizutaii comb. nov. Int J Syst Bacteriol 38, 348-353.

Huß, V. A. R., Festl, H. \& Schleifer, K. H. (1983). Studies on the spectrophotometric determination of DNA hybridization from renaturation rates. Syst Appl Microbiol 4, 184-192.

Jahnke, K. D. (1992). BASIC computer program for evaluation of spectroscopic DNA renaturation data from GILFORD SYSTEM 2600 spectrophotometer on a PC/XT/AT type personal computer. $J$ Microbiol Methods 15, 61-73.

Kim, K.-H., Ten, L. N., Liu, Q.-M., Im, W.-K. \& Lee, S.-T. (2006). Sphingobacterium daejeonense sp. nov., isolated from a compost sample. Int J Syst Evol Microbiol 56, 2031-2036.

Kimura, M. (1980). A simple method for estimating evolutionary rates of base substitutions through comparative studies of nucleotide sequence. J Mol Evol 16, 111-120.

Kimura, M. (1983). The Neutral Theory of Molecular Evolution. Cambridge: Cambridge University Press.

Kumar, S., Tamura, K., Jakobsen, I.-B. \& Nei, M. (2001). MEGA2: Molecular Evolutionary Genetics Analysis software. Bioinformatics 17, 1244-1245.

Lányí, B. (1987). Classical and rapid identification methods for medically important bacteria. Methods Microbiol 19, 1-67.

Mandel, M. \& Marmur, J. (1968). Use of ultraviolet absorbancetemperature profile for determining the guanine plus cytosine content of DNA. Methods Enzymol 12B, 195-206.

Nedashkovskaya, O. I., Kim, S. B., Suzuki, M., Shevchenko, L. S., Lee, M. S., Lee, K. H., Park, M. S., Frolova, G. M., Oh, H. W. \& other authors (2005). Pontibacter actiniarum gen. nov., sp. nov., a novel member of the phylum 'Bacteroidetes', and proposal of Reichenbachiella gen. nov. as a replacement for the illegitimate prokaryotic generic name Reichenbachia Nedashkovskaya et al. 2003. Int J Syst Evol Microbiol 55, 2583-2588.

Park, M., Ryu, S. H., Thi Vu, T.-H., Ro, H.-S., Yun, P.-Y. \& Jeon, C. O. (2007). Flavobacterium defluvii sp. nov., isolated from activated sludge. Int J Syst Evol Microbiol 57, 233-237.

Saitou, N. \& Nei, M. (1987). The neighbor-joining method: a new method for reconstructing phylogenetic trees. Mol Biol Evol 4, 406-425.
Sasser, M. (1990). Identification of bacteria by gas chromatography of cellular fatty acids. USFCC Newsl 20, 16.

Shivaji, S., Ray, M. K., Rao, N. S., Saisree, L., Jagannadham, M. V., Kumar, G. S., Reddy, G. S. N. \& Bhargava, P. M. (1992). Sphingobacterium antarcticus sp. nov., a psychrotrophic bacterium from the soils of Schirmacher Oasis, Antarctica. Int J Syst Bacteriol 42, 102-106.

Stackebrandt, E. \& Goebel, B. M. (1994). Taxonomic note: a place for DNA-DNA reassociation and $16 \mathrm{~S}$ rRNA sequence analysis in the present species definition in bacteriology. Int J Syst Bacteriol 44, 846849.

Steyn, P. L., Segers, P., Vancanneyt, M., Sandra, P., Kersters, K. \& Joubert, J. J. (1998). Classification of heparinolytic bacteria into a new genus, Pedobacter, comprising four species: Pedobacter heparinus comb. nov., Pedobacter piscium comb. nov., Pedobacter africanus sp. nov. and Pedobacter saltans sp. nov. Proposal of the family Sphingobacteriaceae fam. nov. Int J Syst Bacteriol 48, 165-177.

Takeuchi, M. \& Yokota, A. (1992). Proposals of Sphingobacterium faecium sp. nov., Sphingobacterium piscium sp. nov., Sphingobacterium heparinum comb. nov., Sphingobacterium thalpophilum comb. nov. and two genospecies of the genus Sphingobacterium, and synonymy of Flavobacterium yabuuchiae and Sphingobacterium spiritivorum. J Gen Appl Microbiol 38, 465-482.

Thompson, J. D., Gibson, T. J., Plewniak, F., Jeanmougin, F. \& Higgins, D. G. (1997). The CLUSTAL_X windows interface: flexible strategies for multiple sequence alignment aided by quality analysis tools. Nucleic Acids Res 25, 4876-4888.

Wayne, L. G., Brenner, D. J., Colwell, R. R., Grimont, P. A. D., Kandler, O., Krichevsky, M. I., Moore, L. H., Moore, W. E. C., Murray, R. G. E. \& other authors (1987). International Committee on Systematic Bacteriology. Report of the ad hoc committee on reconciliation of approaches to bacterial systematics. Int J Syst Bacteriol 37, 463-464.

Xu, P., Li, W.-J., Tang, S.-K., Zhang, Y.-O., Chen, G.-Z., Chen, H.-H., Xu, L.-H. \& Jiang, C.-L. (2005). Naxibacter alkalitolerans gen. nov., sp. nov., a novel member of the family 'Oxalobacteraceae' isolated from China. Int J Syst Evol Microbiol 55, 1149-1153.

Yabuuchi, E., Kaneko, T., Yano, I., Moss, C. W. \& Miyoshi, N. (1983). Sphingobacterium gen. nov., Sphingobacterium spiritivorum comb. nov., Sphingobacterium multivorum comb. nov., Sphingobacterium mizutae sp. nov., and Flavobacterium indologenes sp. nov.: glucosenonfermenting gram-negative rods in CDC groups IIk-2 and IIb. Int $J$ Syst Bacteriol 33, 580-598.

Yamaguchi, S. \& Yokoe, M. (2000). A novel protein-deamidating enzyme from Chryseobacterium proteolyticum sp. nov., a newly isolated bacterium from soil. Appl Environ Microbiol 66, 3337-3343.

Yoo, S.-H., Weon, H.-Y., Jang, H.-B., Kim, B.-Y., Kwon, S.-W., Go, S.-J. \& Stackebrandt, E. (2007). Sphingobacterium composti sp. nov., isolated from cotton-waste composts. Int J Syst Evol Microbiol 57, 1590-1593.

Yoon, J.-H., Kim, H., Kim, S.-B., Kim, H.-J., Kim, W. Y., Lee, S. T., Goodfellow, M. \& Park, Y.-H. (1996). Identification of Saccharomonospora strains by the use of genomic DNA fragments and rRNA gene probes. Int J Syst Bacteriol 46, 502-505.

Zhou, Y., Dong, J., Wang, X., Huang, X., Zhang, K.-Y., Zhang, Y.-Q., Guo, Y.-F., Lai, R. \& Li, W.-J. (2007). Chryseobacterium flavum sp. nov., isolated from a polluted soil. Int J Syst Evol Microbiol 57, 1765-1769. 